\title{
FAKTOR YANG MEMPENGARUHI PERILAKU TERHADAP KEPATUHAN PENGGUNAAN ALAT PELINDUNG DIRI (APD) UNTUK PENCEGAHAN PENYAKIT AKIBAT KERJA
}

Icha dameyanti br sebayang

Email: ichasebayang19@gmail.com

\section{Latar Belakang}

Rumah sakit merupakan tempat kerja serta tempat berkumpulnya orang-orang sehat baik petugas, pengunjung dan orang-orang sakit (pasien) sehingga rumah sakit merupakan tempat kerja yang mempunyai risiko tinggi terhadap kesehatan maupun penyakit akibat kecelakaan kerja, dan juga karena kontak dengan agen penyakit menular, dengan darah dan cairan tubuh maupun tertusuk jarum, instrumen tajam yang dapat berperan sebagai tranmisi berbagai penyakit, seperti hepatitis B, HIV/AIDS, dan juga potensial sebagai media penularan penyakit yang lain (1).

Kamar operasi merupakan ruangan yang sangat berisiko mengancam terhadap kesehatan petugas khususnya perawat bedah karena banyaknya peralatan yang dipakai untuk keperluan operasi, pemakaian gas anestesi dan stress psikologis tingkat tinggi yang berkepanjangan. Sebuah penelitian di Amerika tentang mekanisme robeknya sarung tangan karet dan terjadinya cedera tertusuk benda tajam pada 2292 operasi selama 3 bulan menemukan $92 \%$ robeknya sarung tangan akibat tidak rangkap dua dan $8 \%$ karena sebab tidak diketahui, kemudian 70 cedera tertusuk benda tajam, 0,7\% akibat jarum, 10\% akibat skalpel dan 23\% akibat yang lain. Peran perawat sangat penting untuk sebuah pelayanan rumah sakit karena tanpa mereka pelayanan rumah sakit menjadi buruk, terlebih perawat bedah yang tenaga mereka sangat diperlukan sekali karena mereka punyakekhususan sendiri dan untuk menjadi seorang perawat bedah yang terampil perlu waktu mendidik dan melatihnya, perlu pengalaman kerja yang lama masuk tim pembedahan (2).Penularan infeksi yang terjadi pada perawat bedah dapat disebabkan oleh tindakan keperawatan yang dilakukan sering kontak dengan darah, jaringan, dan sekresi cairan yang yang masuk kedalam tubuh baik karena tertusuk jarum atau luka, mukosa yang kepercikan oleh darah, cairan yang mengandung kuman dari pasien berpotensi menimbulkan infeksi. Salah satu penyebabnya karena mereka bekerja tidak pakai alat pelindung diri (APD) sarung tangan, mereka tidak patuh menggunakan APD (2). 
Upaya untuk mencegah kecelakaan kerja adalah dengan menghilangkan risiko atau mengendalikan sumber bahaya dan usaha yang terakhir adalah mengunakan alat pelindung diri (APD). Menurut ILO (1989), hierarki pengendalian bahaya terdapat 5 (lima) pengendalian bahaya yaitu eliminasi, substitusi, engineering, administrasi dan alat pelindung diri (APD). Pencegahan tersebut lebih diarahkan pada lingkungan kerja, peralatan, dan terutama adalah pekerja (3).Perilaku kesehatan dan keselamatan kerja perawat di rumah sakit sangat penting, karena tindakan perawat sekecil apapun dapat menimbulkan risiko terhadap perawat dan pasien. Banyak penelitian yang menunjukan rendahnya kepatuhan terhadap penggunaan APD. Data hasil penelitian Aarabi et.al (2008) menyatakan hanya 33,9\% dari 250 tenaga medis yang patuh terhadap standar operasioanal prosedur penggunaan masker (4). Hasil penelitian Ganezak dan Szych (2007) mendeskripsikan hanya 5\% perawat yang peduli dan taat dalam mengunakan sarung tangan, masker, baju pelindung dan kaca mata pelindung

\section{Metode}

Jenis penelitian ini adalah observasional analitik yang bertujuan untuk mengetahui hubunganantara usia, jenis kelamin, lama kerja, pengetahuan, sikap, dan ketersediaan alat pelindung diri (APD dengan perilaku penggunaan APD pada tenaga kesehatan. Desain penelitian yang digunakan adalah cross-sectional. Populasi dalam penelitian ini adalah seluruh perawat, dan karyawan penunjang medis(instalasi farmasi, gizi, dan laboratorium) yang bekerja di RSUD Banjarbaru yang berjumlah 185responden. Berdasarkan perhitungan jumlah sampel dengan rumus Isaac \& Michael dalam Sugiyono(2015) diperoleh jumlah sampel sebanyak 125 responden. Instrumen dalam penelitian ini adalahlembar kuesioner. Analisis bivariate menggunakan uji Chi Square untuk variabel usia, jenis kelamin,lama kerja, dan pengetahuan serta uji Fisher's Exact untuk variabel sikap dan ketersediaan APDdengan derajat kemaknaan $95 \%$.

Penelitian ini dilakukan di RSUD Banjarbaru pada tenaga kesehatan(perawat dan karyawan penunjang medis). Waktu penelitian ini berlangsung selama 8 bulan(FebruariSeptember 2016).Penelitian ini menggunakan pendekatan kuantitatif dngan survei analitik dengan desain cross sectional dalam rangka mempelajari dinamika antar variabel dengan cara pengumpulan data sekaligus pada waktu $(11,12)$. Penelitian dilaksanakan di Instalasi Bedah Sentral RSUD Ulin Banjarmasin tahun 2015 selama tiga bulan dari tanggal 23 Agustus 2015 
sampai dengan tanggal 23 Okober 2015.Populasi penelitian ini adalah seluruh perawat bedah di Instalasi Bedah Sentral RSUD Ulin Banjarmasin dengan yang berjumlah 93 orang dengan besar sampel adalah 81 orang yang dihitung dengan rumus cross sectional study menurut Lameshow dan dipilih dengan cara simple random sampling. Data dikumpulkan dengan menggunakan kuisioner yang terlebih dahulu dilakukan ujicoba dengan hasil uji validitas adalah semua item pertanyaan valid dan instrument reliable (12). Selanjutnya data yang terkumpul dianalisis secara inferensial dengan uji regresi

\section{Hasil Dan Pembahasan}

Prosentasi sikap baik yakni patuh adalah yang tertinggi yakni 86,3\% dan sisanya adalah tidak patuh. Hasil statistik uji t (Uji Parsial) sikap perawat bedah terhadap kepatuhan perawat bedah dalam menggunakan APD di IBS RSUD Ulin Banjarmasin diperoleh nilai p-value $(0,0.117)>0,05$. Dengan demikian dapat disimpulkan bahwa secara parsial variabel sikap perawat bedah berpengaruh tidak signifikan terhadap kepatuhan perawat bedah dalam menggunakan APD di IBS RSUD Ulin Banjarmasin. Hasil penelitian ini sesuai dengan teori perilaku Bloom dalam Notoatmodjo (2012) yang menjelaskan bahwa perilaku merupakan fungsidari faktor predisposisi yaitu faktor yang ada dalam diri individu yang ada didalamnya terdapat sikap dari individu. Sikap responden mempengaruhi tindakan responden dalam menggunakan APD di tempat kerja. Sikap terhadap perilaku menggunakan APD pada penelitian ini lebih banyak positif. Sikap adalah pandangan-pandangan atau perasaan yang disertai kecenderungan untuk bertindak sesuai sikap objek tersebut (14). Prosentase lama bekerja di IBS 5 tahun memiliki kepatuhan 84,1\% dan sisanya yang lebih 5 tahun adalah tidak patuh. Hasil statistik regresi logistik antara lama bekerja respondenterhadap kepatuhan responden dalam menggunakan APD di IBS RSUD Ulin Banjarmasin diperoleh nilai p-value $(0,054)>0,05$. Dengan demikian dapat disimpulkan bahwa secara parsial variabel lama bekerja perawat bedah 
berpengaruh tidak signifikan terhadap kepatuhan perawat bedah dalam menggunakan APD di IBS RSUD Ulin Banjarmasin sehingga. Lama kerja adalah salah satu faktor predisposisi yang mempengaruhi seseorang berperilaku (Green, 1980) dalam Notoadmodjo (1993). Lama kerja seseorang dapat dihubungkan dengan pengalaman yang diperoleh di tempat kerja, semakin lama bekerja semakin mahir (14).

Menurut teori Anderson dalam Notoadmodjo (2012) bahwa, dimana ia berada semakin lama pengalaman kerja seseorang, maka semakin terampil, dan biasanya semakin lama semakin mudah ia memahami tugas, sehingga memberi peluang untuk meningkatkan prestasi serta beradaptasi dengan lingkungan seseorang maka pengalaman yang diperoleh akan semakin baik. Dalam penelitian ini tidak terdapat pengaruh yang signifikan antara lama bekerja dengan perilaku penggunaan APD. Tidak terdapat pengaruh antara responden yang bekerja kurang dari 5 tahun dengan yang lebih dari 5 tahun tentang perilaku penggunaan APD. Hal ini kemungkinan dikarenakan bahwa lama bekerja bukanlah hal utama yang mempengaruhi responden, tetapi juga di pengaruhi oleh pengetahuan yang di miliki dan diperoleh dari pendidikan, bacaan, penelitian dan lain lain (15). Hasil penelitian ini sejalan dengan penelitianHasriani et. all (2009) yang menyatakan tidak terdapat pengaruh antara lama bekerja pada pekerja radiasi dengan perilaku penggunaan APD.Prosentase yang menyatakan ada kebijakan yang patuh 37 (75,6\%) lebih banyak dari responden yang tidak patuh 12 ( 24,4\%) sedangkan yang menyatakan tidak ada kebijakan yang patuh 23(71,9\%) dan responden tidak patuh $9(28,1 \%)$. Hasil statistik regresi logistik kebijakan terhadap kepatuhan perawat bedah dalam menggunakan APD di IBS RSUD Ulin Banjarmasin diperoleh nilai pvalue $(1,000)>0,05$. Dengan demikian dapat disimpulkan bahwa secara parsial variable kebijakan perawat bedah berpengaruh tidak signifikan terhadap kepatuhan Perawat bedah dalam menggunakan APD di IBS RSUD Ulin Banjarmasin. Menurut Green dalam Notoatmoadjo (2012) kebijakan adalah salah satu faktor penguat untuk pendorong terjadinya perilaku.

Peraturan atau kebijakan penggunaan APD di tempat kerja adalah salah satu faktor penguat untuk mendorong responden menggunakan APD dari hasil penelitian bahwa responden patuh penggunaan APD. Hasil penelitian ini menunjukkan bahwa tidak ada pengaruh signifikan kebijakan/ peraturan dari RS terhadap perilaku penggunaan APD (15).Prosentase responden yang menyatakan ada pengawasan patuh $50(84,8 \%)$ lebih banyak dari responden yang tidak 
patuh $9(15,2 \%)$ sedangkan yang menyatakan tidak ada pengawasan yang patuh $10(45 \%)$, dan yang tidak patuh 12 (55\%). Hasil statistik uji $\mathrm{r}$ nilai regresi logistika pengawasan terhadap kepatuhan perawat bedah dalam menggunakan APD di IBS RSUD Ulin Banjarmasin diperoleh nilai $\mathrm{P}$ value $(0,016)<0,05$. Dengan demikian dapat disimpulkan bahwa secara parsial variabel pengawasan berpengaruh signifikan terhadap kepatuhan perawat bedah dalam menggunakan APD di IBS RSUD Ulin. Hasil penelitian ini sesuai dengan penelitian terdahulu Aripin (2006) yang menyatakan bahwa responden yang mendapatlan dukungan pengawasan dari pimpinannya berpeluang lebih patuh sebesar 21 kali dibandingkan dengan responden yang kurang mendapat dukungan pengawasan dari pimpinannya. Penelitian lain yang sependapat Madyanti (2011) menyebutkan dari hasil penelitianya terhadap kepatuhan bidan menggunakan APD pada waktu menolong persalinan terdapat pengaruh yang bermakna antara dukungan/komitmen pimpinan terhadap kepatuhan menerapkan SOP.

Pengawasan bertujuan untuk memastikan behwa kegiatan yang dilakukan berjalan dengan rencana (9). Prosentase respondenyang menyatakan keterdiaan APD di tempat kerja tersedia, patuh $45(69,3 \%)$ dan tidak patuh $20(30,7 \%)$ sedangkan yang menyatakan persediaan APD ditempat kerja tidak ada berperilaku yang patuh $15(93,7 \%)$ dan tidak patuh $1(6,3 \%)$. Hasil statistik uji regresi logistiknilai ketersediaan APD terhadap kepatuhan perawat bedah dalam menggunakan APD di IBS RSUD Ulin Banjarmasin diperoleh nilai pvalue $(0,003)<0,05$. Dengan demikian dapat disimpulkan bahwa secara parsial variabel ketersediaan APD berpengaruh signifikan terhadap kepatuhan perawat bedah dalam menggunakan APD di IBS RSUD Ulin Banjarmasin. Penelitian lain yang mendukung Idayati (2008), bahwa hubungan pelatihan dan ketersediaan sarana. Prosentase responden yang menyatakan ada pengaruh teman sejawat, tidak patuh $13(46,4 \%)$ dan patuh 15 (53,6\%) sedangkan yang menyatakan tidak ada pengaruh teman sejawat, tidak patuh $8(15 \%)$ dan yang patuh $45(85 \%)$. Hasil statistik uji regresi logistik nilai pengaruh teman sejawat terhadap kepatuhan perawat bedah dalam menggunakan APD di IBS RSUD Ulin Banjarmasin diperoleh nilai pvalue $(0,137)>0,05$. Dengan demikian dapat disimpulkan bahwa secara parsial variabel teman sejawat berpengaruh tidak signifikan terhadap kepatuhan perawat bedah dalam menggunakan APD di IBS RSUD Ulin Banjarmasin. Hasil penelitian ini menunjukkan tidak signifikan ada pengaruh antara pengaruh dari teman sejawat dengan perilaku penggunaan APD Menurut Notoadmodjo (2007), pengaruh interpersonal (keluarga, sejawat, tenaga kesehatan, dukungan sosial dan contoh model 
merupakan hal yang mempengaruhi karakteristik dan pengalaman seseorang. Hal ini dihubungkan dengan persepsi mereka terhadap penyakit yang ditimbulkan sangat berbahaya. Ini merupakan suatu kejadian yang sangat baik dan menguntungkan baik untuk diri responden sendiri maupun orang lain. Madyanti (2012) dalam penelitiannya menyatakan hal yang sesuai bahwa faktor lingkungan yaitu ada tidaknya rekan kerja yang menggunakan APD ketika melakukan pertolongan persalinan mempengaruhi mereka dalam menggunakan APD. Pengaruh norma sosial dan pengaruh lingkungan seperti keluarga atau teman sejawat merupakan hal yang juga mempengaruhi perilaku seseorang. Hasil penelitian ini responden menyatakan kepatuhannya karena ada pengaruh teman sejawat (9).

Prosentase responden yang persepsi baik, tidak patuh $11(25,5 \%)$ dan patuh $32(74,5 \%)$ sedangkan yang punya persepsi tidak baik, tidak patuh 10 (26,3\%) dan yang patuh 28 (73,7\%). Hasil statistik uji regresi logistik nilai pengaruh persepsi perawat bedah terhadap kepatuhan perawat bedah dalam menggunakan APD di IBS RSUD Ulin Banjarmasin diperoleh nilai p-value $(0,068)>0,05$ Dengan demikian dapat disimpulkan bahwa secara parsial variabel persepsi berpengaruh tidak signifikan terhadap kepatuhan perawat bedah dalam menggunakan APD di IBS RSUD Ulin Banjarmasin. Dari hasil pengamatan peneliti, semua APD telah tersedia dan mencukupi, namun terlihat kurang bersih. Hal ini juga yang dikeluhkan oleh para responden, diketahui pada responden yang berusia > 35 tahun lebih banyak (62,5\%)yang berperilaku baik dalam penggunaan APD dibandingkan berperilaku kurang (37,5\%). Begitu pularesponden yang berusia $\leq 35$ tahun lebih banyak $(85,7 \%)$ yang berperilaku baik dalam penggunaanAPD dibandingkan berperilaku kurang (14,3\%). Sehingga dapat diketahui bahwa terdapat hubunganyang sangat signifikan antara usia dengan perilaku penggunaan APD pada tenaga kesehatan diRSUD Banjarbaru dengan hasil uji statistik Chi-square didapatkan nilai (pvalue $=0,006$ ).

Hasil penelitian ini sejalan dengan penelitian Supiana (2013) yang menyatakan bahwa adahubungan yang signifikan antara usia dengan penggunaan APD pada bidan pelayanan kebidanan dirumah KIA Sadewa Yogyakarta $(\mathrm{p}=0,0001)$ (8). Namun tidak sejalan dengan penelitian Agustina(2015) yang menyatakan bahwa tidak ada hubungan antara usia dengan perilaku pemakaian alatpelindung diri (APD) $(\mathrm{p}=1,000)(9)$.Usia 20-25 tahun merupakan periode pertama pengenalan dengan dunia orang dewasa,seseorang dalam periode ini akan mulai mencari 
tempat dunia kerja dan dunia hubungan sosial.Sedangkan usia 26-35 tahun berdasarkan periode kehidupan, usia ini menjadi penting karena padaperiode ini struktur kehidupan menjadi lebih tetap dan stabil. Semakin cukup usia seseorang, tingkatdiketahui pada responden yang berjenis kelamin Perempuan lebih banyak(76,1\%) yang berperilaku baik dalam penggunaan APD, dibandingkan berperilaku kurang $(23,9 \%)$.

Demikian pula responden laki-laki lebih banyak (78,8\%) yang berperilaku baik dalam penggunaanAPD, dibandingkan berperilaku kurang $(21,2 \%)$. Sehingga dapat diketahui bahwa tidak terdapathubungan yang signifikan antara jenis kelamin dengan perilaku penggunaan APD pada tenagakesehatan di RSUD Banjarbaru dengan hasil uji statistik Chi-square didapatkan nilai (p-value=0,940).Hasil penelitian ini sejalan dengan penelitian Wibowo (2013) yang menyatakanbahwa tidak adahubungan antara jenis kelamin perawat dengan penggunaan sarung tangan $(\mathrm{p}=0,136)$. Hal ini karenaapapun jenis kelaminnya tidak mempengaruhi menggunakan atau tidak menggunakan APD. Jeniskelamin laki-laki atau perempuan mempunyai kesempatan yang sama untuk menggunakan atau tidakmenggunakan APD. Bady (2007) dalam penelitiannya menyatakan responden yang tersebar di limaruang rawat inap menunjukkan bahwa SDM perawat didominasi oleh jenis kelamin perempuan.

Hal initerjadi karena lazimnya profesi keperawatan lebih banyak diminati kaum perempuan, mengingat profesi keperawatan lebih dekat dengan masalah-masalah mother instinct, meskipun di era globalisasiatau alasan lain misalnya kesetaraan gender atau juga karena faktor kebutuhan di ruang UGD, OK, dan lain-lain atau mungkin juga karena perkembangan ilmu pengetahuan dan teknologi maka jumlah perawat laki-laki juga mulai dipertimbangkan dan diperhitungkan diketahui pada responden yang pengetahuan kurang lebih banyak (100\%)mempunyai perilaku baik dalam penggunaan APD, dibandingkan dengan responden yang berperilaku kurang $(0 \%)$. Sedangkan pada responden yang pengetahuan baik lebih banyak berperilaku baik(66,3\%), dibandingkan dengan responden yang berperilaku kurang $(33,7 \%)$. Sehingga dapat diketahuibahwa terdapat hubungan yang sangat signifikan antara pengetahuan dengan perilaku penggunaanAPD pada tenaga kesehatan di RSUD Banjarbaru dengan hasil uji statistik Chi-square didapatkannilai (p-value=0,0001). Hasil penelitian menjelaskan bahwa terdapat 29 responden yang berperilaku kurang baik dalampenggunaan APD, namun sebenarnya memiliki pengetahuan yang baik mengenai APD. Hal tersebutdiduga karena pengalaman pekerja 
yang menyatakan bahwa pemakaian APD tergantung denganpasien yang akan ditangani. Sedangkan responden yang berpengetahuan kurang justru memiliki perilaku yang baik terhadap penggunaan APD yaitu sebanyak 39 responden.

Hasil penelitian ini sejalan dengan penelitian Saputro (2015), diketahui bahwa ada hubungan antara pengetahuan dengan penggunaan APD $(\mathrm{p}=0,002)$. Namun, pada penelitian Putra (2012), diketahui bahwa tidak ada hubungan antara pengetahuan dengan penggunaan alat pelindung diri $(\mathrm{p}=0,465)$ (14).Menurut Green dalam Notoadmodjo (2007), peningkatan pengetahuan tidak selalu menyebabkan perubahan perilaku, namun hubungan positif antara kedua variabel ini telah diperlihatkan dalam sejumlah penelitian yang dilakukan sampai saat ini. Pengetahuan tertentu tentang penggunaan APD mungkin penting sebelum suatu tindakan penggunaan APD terjadi, tetapi tindakan penggunaan APD yang diharapkan mungkin tidak akan terjadi kecuali apabila pekerja mendapat isyarat yang cukup kuat untuk memotivasinya bertindak atas dasar pengetahuan yang dimilikinya Hasil penelitian ini menjelaskan bahwa terdapat 6 responden yang berperilaku baik dalam penggunaan APD, namun tidak didukung dengan sikap penggunaan APD yang baik. Sebaliknya,terdapat 19 responden yang berperilaku kurang baik dalam penggunaan APD, namun sebenarnya memiliki sikap yang baik terhadap penggunaan APD. Hasil ini masih konsisten dengan penelitian Putra (2012), bahwa ada hubungan antara sikap dengan penggunaan alat pelindung diri dengan nilai $(\mathrm{p}=0,004)(12)$. Hal ini dapat dipahami karena sikap merupakan suatu konsep paling penting dalam psikologi sosial. Sikap juga dapat diartikan sebagai kesiapan untuk bereaksi terhadap suatu stimulusdengan cara tertentu, apabila dihadapkan pada suatu stimulus yang menghendaki adanya respon.Suatu pola perilaku, tendenasi atau kesiapan antisipatif untuk menyesuaikan diri dari situasi social yang telah terkondisikan (16). Namun, penelitian ini tidak sejalan dengan penelitian Sihombing (2014), diketahui bahwa tidak ada hubungan antara sikap dengan dengan penggunaan alat pelindungdiri $(p=0,058)(17)$. hal ini perlu mendapat perhatian dari pihak rumah sakit terutama mengenai kebersihan APD khususnya sepatu dan celemek.

Sebaiknya di setiap SOP atau kebijakan yang di buat di jelaskan secara rinci pembagian tugas termasuk siapa yang bertugas untuk membersihkan APD. Dalam hal membersihkan APD tersebut, sebaiknya setiap petugas wajib membersihkan APD yang telah dipakainya.Prosentase responden yang menyatakan ada pengaruh media massa, patuh 15 (75\%) dan tidak patuh 5 
(25\%) sedangkan yang menyatakan tidak ada pengaruh, tidak patuh $16(26,2 \%)$ dan yang patuh $45(73,8 \%)$. Hasil satistik Uji regresi logistik antara pengaruh media massa terhadap kepatuhan perawat bedah dalam menggunaka APD di IBS RSUD Ulin Banjarmasin diperoleh nilai p-value $(0,677)>0,05$. Dengan demikian dapat disimpulkan bahwa secara parsial variabel pengaruh media massa berpengaruhi tidak signifikan terhadap kepatuhan perawat bedah dalam menggunakan APD di IBS RSUD Ulin Banjarmasin. Menurut teori komunikasi dalam Rohim. S (2009), media massa merupakan alat pada suatu proses komunikasi, media mssa sebagai sumber pada saat yang bersamaan individu yang melihat dan mendengar dikatakan sebagai penerima. Media massa merupakan suatu alat penyampai pesan yang sangat efektif (16). Dalam penelitian ini yang menyatakan tidak ada pengaruh media massa berperilaku patuh. Hasil penelitian ini sesuai dengan penelitian Madyanti (2012) sebagian besar responden yang dilakunya penelitian menyatakan bahwa media massa yang paling baik menyampaikan pengetahuan tentang APD adalah pemberitahuan dari rumah sakit, yaitu sebesar 75,8 \%, diikuti televisi 18,2\% dan lainnya $6,1 \%$.

Jadi menurut penelitian ini media massa atau elektronik tidak efektif dalam menyampaikapesan kepatuhan, mereka lebih tertarik dengan informasi dari rumah sakit (9).pengawasan,sikap,lama bekerja, kebijakan, pengawasan, ketersediaan APD, teman sejawat, media massa/elektronik dan persepsi terhadap kepatuhan perawat dalam menggunan APD di IBS RSUD Banjarmasin secara simultan dengan menggunakan uji nagelkerke adalah diterima yakni pada model kedua yaitu hasil dari Step 4. Hasil uji koefiesin determinasi (tabel 4) nilai adalah sebesar 0,841 ini berarti bahwa pengaruh antara Sikap (X2), Lama Kerja (X3), Pengawasan (X5), Ketersediaan APD (X6), Teman Sejawat (X7), Persepsi (X8) perawat bedah terhadap Kepatuhan Perawat bedah dalam menggunakan APD sangat kurang kuat karena nilainya lebih dari 0,5. Angka R2 atau koefisien determinasi adalah 0,841 diartikan 84,1\% berpengaruh secara bersama-sama. Hal ini berarti $84,1 \%$ faktor perilaku yang menjadi variabel penelitian ini yang terdiri dari Sikap (X2), Lama Kerja (X3), Pengawasan (X5), Ketersediaan APD (X6), Teman Sejawat (X7), Persepsi (X8), sedangkan sisanya 15,9\% dijelaskan oleh faktor-faktor lain yang tidak dimasukkan di dalam model. Hal ini menunjukkan bahwa masih ada faktor-faktor lain di luar variabel-variabel yang digunakan dalam penelitian ini yang bisa mempengaruhi kepatuhan perawat dalam menggunakan APDdi IBS RSUD Ulin Banjarmasin. 


\section{Penutup}

Penelitian ini menyimpulkan bahwa berdasarkan analisa regresi logistik, dapat dilihat bahwa yang paling berpengaruh terhadap variabel kepatuhan adalah variabel pengawasan dengan nilai koefisien regresi sebesar 0,700(70,0\%) dan variabel ketersediaan APD dengan nilai kofisien regresi sebesar 0,678 (67,8\%).Terdapat pengaruh yang signifikan penketersediaan APD terhadap kepatuhan penggunaan APD di IBS RSUD Ulin Banjarmasin. Terdapat pengaruh yang tidak signifikan dari variabel pengetahuan, sikap, lama bekerja, kebijakan,teman sejawat, media massapersepsi terhadapkepatuhan penggunaan APD di IBS RSUD Ulin Banjarmasin. Berdasarkan uji simultan adalah $84,1 \%$, sangat kuat bahwa kepatuhan perawat bedah benarbenar nyata/signifikan dipengaruhi faktor perilaku yang menjadi variabel dalam penelitian ini yaitu: sikap, lama kerja, pengawasan, ketersediaan APD, teman sejawat, persepsi dan hanya $15,9 \%$ saja faktor lain di luar variabel-variabel yang digunakan dalam penelitian ini yang bisa mempenga IBS RSUD Ulin Banjarmasin

Berdasarkan kesimpulan hasil penelitian seperti yang diuraikan di atas, maka direkomendasikan beberapa saran (1) Pihak manajemen RSUD Ulin Banjarmasin. Pengawasan pada perawat terhadap kepatuhan perawat dalam mengunakan APD perlu lebih ditingkatkan lagi sehingga dapat meningkatkan kualitas mutu pelayanan di kamar bedah. Ketersediaan APD di kamar operasi perlu dipertahankan dan ditingkatkan agar lebih mendukung tercapainya kepatuhan perawat bedah sehingga dapat meningkatkan kualitas mutu pelayanan di kamar bedah; (2) Untuk meningkatkan kepatuhan penggunaan APD di kamar operasi perlu dilakukan sosialisasi, pendidikaan dan pelatihan yang berkelanjutan setiap orientasi pegawai baru masuk di IBS RSUD Ulin Banjarmasin. Perlunya memberikan reward atau penghargaan pada petugas yang baik patuh menggunakan APD setiap melakukan pekerjaan atau bekerja, dan punishmentatau hukuman pada petugas yang melakukan pelanggaran ketentuan pemakaian APD pada waktu bekerja; (3)

Penelitian yang akan datang. Untuk menindaklanjuti hasil penelitian ini perlu diteliti lebih mendalam dengan menggunakan variabel yang menyangkut aspek yang sama dengan menambah variabel yang lain agar hasil yang didapatkan jauh lebih bermakna Terdapat 
hubungan yang signifikan antara usia, lama kerja, pengetahuan dan sikap denganperilaku penggunaan APD pada tenaga kesehatan di RSUD Banjarbaru. Bagi RSUD Banjarbaru agar dapat memberikan sosialisasi, penyuluhan, pelatihan atau workshop mengenai penggunaan APD yang baik dan benar serta sesuai dengan prosedur dan peraturan yang ada untuk meningkatkanpengetahuan dan sikap tenaga kesehatan. Perlu juga disediakan APD yang lengkap sesuai denganprosedur kerja petugas tiap-tiap instalasi untuk mencegah terjadinya kecelakaan maupun penyakitakibat kerja. Pihak RSUD Banjarbaru juga dapat menerapkan reward dan punishment kepadapekerja, khususnya tenaga kesehatan dalam penggunaan APD yang baik dan benar. Sehingga dapat mengubah perilaku yang masih kurang baik dan meningkatkan perilaku baik dalam penggunaan APD.

\section{Daftar Pustaka}

Aarabi A, Effat KL, Gholami H. Health Care Personnel Compliance With Standards Of Eye And Face Protection And Mask Usage In Operating Room Iranian. Journal of Nursing and Midwifery Research. 2008; 13 (2): 50-64

Pamuji T, Asrin A, Kamaluddin R. Hubungan Pengetahuan Perawat Tentang Prosedur Operasional (SPO) Dengan Kepatuhan Perawat Terhadap Pelaksanaan SPO Profesi Pelayanan Keperawatan Di Instalasi Rawat Inap RSUD Probolingga. Jurnal Keperawatan Soedirman. 2008; 3 (1): $1-9$.

Idayanti. Hubungan Pengetahnan Dan Sikap Perawat Terhadap Penerapan Standard Operational Procedure (SOP) Teknik Menyuntik Dalam Upaya Pencegahan Infeksi Di Rsud Arifin Achmad Pekanbaru. Tesis. Medan: USU Medan; 2008.

Rohim S. Teori Komunikasi Perspektif,Ragam dan Aplikasi, Jakarta; PT Rineka Cipta; 2009.

Ganezak M, Szych Z. Surgical nurse and compliance with personal protective equifment. Journal of hospital infection. 2008; 66: 346-51.

Supiana N. Hubungan faktor predisposing, enabling, dan reinforcing dengan penggunaan APDpada bidang dalam pelayanan kebidanan di RSKIA Sadewa Yogyakarta tahun 2013. Artikelpenelitian. Yogyakarta: Stikes 'Aisyiyah, 2013 
Pratama MA. Efektivitas sosialisasi program kesehatan dan keselamatan kerja (K3) terhadappengetahuan dan kepatuhan penggunaan alat pelindung diri (APD) pada karyawan penunjangmedis di Rumah Sakit PKU Muhammadiyah Yogyakarta Unit II. Artikel Penelitian. Yogyakarta:Universitas Muhammadiyah Yogyakarta, 2014.

Agustina DE. Perilaku pemakaian alat pelindung diri (APD) (Studi di Bagian Coal and AshHandling PT. PJB UBJ O\&M PLTU Paiton 9). Artikel penelitian. Jember: Universitas Jember, 2015.

Putri A. Faktor - faktor yang berhubungan dengan kepatuhan penerapan prinsip kewaspadaanuniversal (universal precaution) oleh perawat di Instalasi Gawat Darurat RSUP DR. Djamil PadangTahun 2010. Skripsi. Padang: Universitas Andalas, 2011.

Jumata V. Hubungan motivasi dengan sikap perawat dalam penggunaan alat pelindung dirisarung tangan di ruang rawat inap Rumah Sakit Kepolisian Pusat Raden Said Sukanto Jakarta.Skripsi. Jakarta: Fakultas Ilmu Kesehatan Universitas Pembangunan Nasional Veteran, 2010

Simamora, R. H. (2020). Pelatihan Komunikasi Efektif untuk Meningkatkan Efikasi diri Perawat dalam Pelaksanaan Identifikasi Pasien. JURNAL ILMIAH KESEHATAN MASYARAKAT: Media Komunikasi Komunitas Kesehatan Masyarakat, 12(1), 49-54.

Simamora, R. H. (2011). ROLE CONFLICT OF NURSE RELATIONSHIP WITH PERFORMANCE IN THE EMERGENCY UNIT OF HOSPITALS RSD DR. SOEBANDI JEMBER. The Malaysian Journal of Nursing, 3(2), 23-32. 